\title{
DIRECTIONS IN THE STUDY OF EARLY MODERN REFORMED THOUGHT
}

\author{
RICHARD A. MULLER*
}

Calvin Theological Seminary

\begin{abstract}
Given both the advances in understanding of early modern Reformed theology made in the last thirty years, the massive multiplication of available sources, the significant literature that has appeared in collateral fields, there is a series of highly promising directions for further study. These include archival research into the life, work, and interrelationships of various thinkers, contextual examination of larger numbers of thinkers, study of academic faculties, the interrelationships between theology, philosophy, science, and law, and the interactions positive as well as negative between different confessionalities.
\end{abstract}

KEY WORDS: Reformed orthodoxy, post-Reformation Reformed thought, early modernity, exegesis, philosophy

\section{Recent Advances in Research}

The study of early modern Reformed thought has altered dramatically in the last several decades. The once dominant picture of Calvin as the prime mover of the Reformed tradition and sole index to its theological integrity has largely disappeared from view, as has the coordinate view of 'Calvinism' as a monolithic theology and the worry over whether later Reformed thought remained 'true' to Calvin. The relatively neglected field of seventeenth-century Reformed thought has expanded and developed both in the number of diverse thinkers examined and in the variety of approaches to the materials. (Given the number of recent published studies of early modern Reformed thought, the following essay makes no attempt to offer a full bibliography, but only to provide examples of various types of research. Readers are invited to explore the excellent bibliographies found in many of the recent works cited here.)

There are several explanations for the development of this field. The positive study of late medieval backgrounds by scholars of the Reformation has altered assumptions about the nature and character of Protestant thought.

* RICHARD A. MUlLER (PhD 1976, Duke University) is P. J. Zondervan professor emeritus of historical theology at Calvin Theological Seminary, Grand Rapids, United States of America. Email: mullri@calvinseminary.edu. 
Revisionist work on the nature and character of scholasticism and humanism and of the early modern humanist-scholastic debate and interaction has changed the way that scholarship approaches both Reformation and postReformation Protestant thought. Predecessors and contemporaries of Calvin, like Zwingli, Bucer, Bullinger, Vermigli, and Musculus, have received significant examination, as have patterns of Calvin's reliance on and relation to them. Given what can be called the demotion of Calvin from the place of founder and norm for the whole Reformed tradition, studies of later sixteenth-century and seventeenth-century Reformed writers have examined their thought in its own right as representing forms of contextually located theology or, indeed, theologies. Social and institutional histories of early modernity have provided a clearer sense of the contexts for theological formulation. And scholarship on early modern Protestant receptions of the older tradition, whether patristic or medieval, has shed new light on theological formulation itself. Beyond these points, the examination of Reformation and post-Reformation Protestant thought as intellectual history has led to the correlation of theological studies with a wider range of primary and secondary sources concerning the impact of the Renaissance, the long history of scholasticism rightly understood as primarily a matter of method, and the complexity of philosophy in the early modern era.

\section{Multiplication of Resources}

These patterns of examination of early modern Reformed materials have been supported by a vast proliferation of resources. Forty years ago many of the early modern writers whose names are now commonplace to researchers had been scarcely heard of-and when heard of, their writings were incredibly difficult to examine en masse, given their dispersion in rare book libraries across Europe and America. The older secondary literature, largely nineteenth-century European, was not fully bibilographized and, similarly, was often quite difficult to piece together given its dispersion into many geographically disparate libraries. Unpublished manuscript materials were even more difficult to identify and the usual method of access involved extended international travel. That situation, largely because of on-line catalogues and digitization projects, has largely disappeared. Scholars now can not only find out about the literature, they can also do major preliminary work on-line, locate major archival sources, identify a massive number of previously either unknown or inaccessible primary printed materials, and easily gather a vast array of relevant secondary materials.

Some specification concerning specific lines of research is in order. First some further comment on the accessibility of sources and digital research. In addition to well-known older on-line projects like Early English Books Online (EEBO) and Eighteenth-Century Collections Online (ECCO), covering books 
printed in Britain or anywhere in English from the beginnings of printing to 1800 , there are now major digitization projects that are opening up rare book libraries throughout Europe and North America, such as the Herzog August Bibliothek in Wolffenbüttel, the Bibliotheque Nationale de France, the Bayrisches Staatsbibliothek, and Google Books. The contents of these and other digitization projects are surveyed and listed in the online database of the Junius Institute, the Post-Reformation Digital Library (PRDL.org), which is searchable by author, title key word, academic institutional and confessional affiliations, as well as by an increasing number of topical identifications. Most libraries now have well-designed online catalogues, searchable internationally via LibWeb at <http://www.lib-web.org/ > Some of these libraries are also beginning to offer online catalogues of their manuscript archives and even to digitize manuscripts. Two such significant projects are the Oxford University 'Early Modern Letters Online' and 'Early Manuscripts at Oxford University'.

Whereas several decades ago, only the printed works and correspondence of major Reformers like Zwingli, Melanchthon, and Calvin were readily accessible, giving the impression or permitting the excuse that other thinkers need not be investigated, now there is a vast resource not only to their lessfamous contemporaries but also to the late sixteenth- and seventeenth-century materials. The entire framework of research has changed, if only by massively multiplying documentation of individuals and institutions.

\section{Personal and Institutional Networks}

Among the several promising newer directions in scholarship on early modern Reformed thought is the identification and analysis of backgrounds, personal networks, institutional associations, and ecclesial or political contexts. By personal networks and institutional associations I mean the interrelationships of individuals that are not always obvious in printed books but that become clear in the examination of various kinds of archival materials, such as letters, academic registers, city and parish records, and so forth. Increasing access to such materials enables access to more proximate understandings of intentions and acts, often to ongoing dialogues that reveal the backgrounds to and sub-histories of major ecclesial and political events, not to mention publications. Correspondence in particular can reveal issues of chronological development and interactions not otherwise registered, as illustrated in the case of reaction to the thought of John Cameron that ultimately led to the controversies surrounding the theology of Saumur (Gootjes forthcoming). Another significant example is the network of correspondence concerning Protestant inter-confessional irenicism and union, advances in science and education, and a host of related philosophical currents, that is associated with 
the efforts of Samuel Hartlib, now gathered online in 'The Hartlib Papers' at $<$ http://www.hrionline.ac.uk/hartlib/context>.

Another such direction that can be developed in detail arises by means of the enormous number of available academic disputations, whether disputations conducted as part of the work associated with courses given by particular professors or the disputations conducted for the degree. At least in Reformed circles, these disputations, also identified as theses or aphorisms, can be regarded with confidence as reflecting the views, in brief thetical form, of the presiding professor (Stanglin 2010). Study of disputations enables several lines of research. As often gathered for publication in a professor's Opera, they provide an outline or synopsis of his thought on a wide variety of topics and in some cases reveal a process of development leading from short theses to later, elaborated bodies of doctrine. Given that the disputations were public exercises, they also serve to identify a public or institutional theology of a particular university or academy and, together with research on the backgrounds and later work of the student respondents, can begin to illuminate trajectories of thought and influence (Appold 2004; Rester 2016).

Given that we now have an increasing mass of these academic disputations together with the published works of the presiding professors and their colleagues, as collated by academic institution in the 'Scholastica' function of PRDL, further work can be done to examine not only lines of argument and debate associated with individual theologians, but also with faculties of theology and philosophy. Coupled with other identifiers of location-cities, parishes, episcopal sees (among the British)—work can be done on the distinctive characteristics of Reformed thought in particular national and local contexts.

The disputations also raise the issue of academic developments leading from the Reformation into what can loosely be called the early orthodox era. With the rise of Reformed academic centers, disputation both as an intellectual exercise and as training toward degrees was a regular practice (De Boer 2012), leading to more formal theological argumentation than found in the manuals of doctrine produced by the reformers of the first and second generations. More study of developing academic practice is in order as is further analysis of the increasing efforts of Reformed thinkers to appropriate the work of the fathers and medievals for Protestant theology, particularly as these developments contributed to the rise of scholastic orthodoxy in such writers as Zacharias Ursinus, Lambert Daneau (Fatio 1976), Girolamo Zanchi, Benedictus Aretius, and somewhat later, Johannes Scharpius, William Perkins, Bartholomäus Keckermann, Abraham Scultetus, and others of their generation. This too is the era of political and social confessionalization, the impact of which on theological formulation, particularly in academic contexts deserves further study. 
Religious and political solidification of confessional lines led also to increasingly detailed polemic and also to increasingly detailed interaction with the writings of opponents. The older scholarship did recognize the importance of polemic, notably with Cardinal Bellarmine and Gilbertus Genebrardus, for the development of Reformed orthodoxy. The same can be said for debate with Lutheran theologians. Further study along these lines can examine both negative and positive interactions and also the relationship between the polemics and the intention on the part of Reformed writers to emphasize the catholicity of the Reformed faith, identify Protestantism as the 'true church', and, accordingly, to appropriate what they regarded as the best of the church's tradition for Protestantism (Milton 1995).

From the mid seventeenth century, the case of Claude Pajon exemplifies several directions of the new research, among them the importance of archival work, institutional location, and national ecclesial context. Given that all of Pajon's major works were circulated in manuscript form, examination and collation of the manuscripts and careful contextual analysis reveals much not only about Pajon's own thought but also about the nature of French Reformed controversy and also about the several trajectories of thought that emanated from the Academy of Saumur (Gootjes 2014). Further research not only on Saumur but also on the other French Reformed academies, their development, interactions, controversies, and impact of their graduates will be a significant field of inquiry. The research will need to continue the lines of archival research and examine the interrelationship of thinkers and institutions, often via their correspondence.

The same should be noted of the Reformed academies and universities of central Europe, ranging from Bremen, to Herborn and Heidelberg, Basel and Zurich, to Danzig and Alba Iulia in Transylvania. Significant work has been done, for example, on the thought and academic perigrination of Johann Heinrich Alsted and on the impact of Ramism in the German academies (Hotson 2000, 2007), on the thought of Thomas Erastus at Heidelberg (Gunnoe 2011), and on academic and ministerial formation in Geneva and Basel (Maag 1995; Burnett 2006). Expanded availability of sources should lead to more such studies tracing institutional developments through several generations of faculty, identifying contexts and influences in British universities and French academies as well. There has been, moreover, a significant expansion of interest in the history of universities that provides collateral research, often clarifying developments in theological faculties (Freedman 1994, 2005; Feingold and Navarro-Brotons 2006).

\section{Biographical and Topical Studies}

There is also a series of types of more topical and contextualized biographical research that, again, when continued contextually, will bear further fruit. 
The intricacies of covenant theology remain to be worked out beyond the recent analysis of Cocceius' life and significant recasting of his thought and analysis of Cocceius' life by Van Asselt (Van Asselt 1997, 2001). In particular, the study of post-Cocceian controversy developments in covenantal thought, examining such figures as Burman, Van der Wayen, Witsius, and Vitringa is a desideratum. In the case of Witsius, recent work has been done that has highlighted his international connection in the antinomian debates of the late seventeenth century (Van den Brink 2008, 2016). More work needs to be done here on the regional and international developments of thought, the connections between biblical exegesis, legal and political issues and language, and theological formulation, as well as the eschatological dimensions of covenantal thought (Van Asselt, 1996, 2000).

Cocceius is not the only major theological thinker of the era who has been contextually studied. Noteworthy here are studies of Gisbertus Voetius' doctrine of God (Beck 2007), James Ussher's soteriology (Snoddy 2014) and the carefully contextualized studies of Samuel Rutherford (Coffey 1997), John Goodwin (Coffey 2006), John Owen (Gribben 2016), Richard Baxter (Burton 2012; Sytsma forthcoming), and Louis Tronchin (Fatio 2015). Needless to say, more needs to be done biographically, offering contextualized intellectual history studies of more of the significant writers and thinkers of the era. In many cases, such as Voetius, Francis Spanheim, Andreas Rivetus, Francis Turretin, and Jean-Alphonse Turretin, the last major biographical studies were written in the nineteenth century. And beyond these better-known thinkers, there needs to be further identification and study of the less-known writers in order to achieve a clearer picture of the development, breadth, and complexity of Reformed thought.

In the area of topical study, there have been several significant works on the theological controversies of the era that underline the stresses and strains placed on traditional theology by exegetical and philosophical change-specifically in debates over the doctrine of the Trinity (Lim 2012) and the challenge of Socinianism (Mortimer 2010). Other studies have emphasized the presence of varied lines of thought and the diversity of the Reformed tradition (Moore 2007; Haykin and Jones 2011), the former examining seventeenth-century the development of English hypothetical universalism, the latter including a series of essay on topics of debate such as the obedience of Christ, lapsarian issues, hypothetical universalism, eccelesiology, and eschatology. Further study along all of these lines is called for-particularly with a view to uncovering further the diversity of the tradition and the nature of its debates, both theological and philosophical, namely, the debates that evidence varied streams of thought, some of which are in common with other confessionalities but others of which belong to the Reformed tradition itself, 
sometimes identifying confessional boundaries, but other times simply identifying the diversity of Reformed thought.

There is also a significant development in understanding English or British Reformed thought, ranging from major reassessments of the work of Richard Hooker (Atkinson 1997; Kirby 2000) as belonging firmly within a Reformed model, to studies of the persistence of Reformed or 'Calvinistic' thought in the Anglican church after the Restoration (Hampton 2007; Wallace 2011). In furthering this line of research the breadth of the Reformed tradition must continue to be noted as well as the highly problematic use of a notion of 'Calvinism' as a marker for what is Reformed (Muller 2012, 5169; Van den Brink and Höpfl 2014, 8-10). In the case of British thought, there is not only the presence of several major confessional documents belonging to the Reformed family (the Thirty-Nine Articles, the Lambeth Articles, Irish Articles, and the Westminster Confession of Faith), there is also the matter of the varied sources and thinkers who contributed to British Reformed thought, including its Puritan varieties (Pederson 2015), very few of whom can be simply identified as followers of Calvin.

\section{Interactions with Philosophy and the Sciences}

The intersections of theological thought with other thought forms also represent some of the most fruitful possibilities for further research. There are two areas here, also profoundly interrelated that require notice. First and perhaps most obvious, philosophy. The older scholarship recognized the connection between Reformed orthodox theology and the modified Aristotelian or Peripatetic tradition. Beyond, however, a rather a-historical antipathy to all things Aristotelian, the older scholarship typically did not recognize the modifications that took place in the Peripatetic tradition during the later Middle Ages and the Renaissance, not to mention the early modern era.

Several recent works have looked in more detail at medieval backgrounds to Reformed orthodoxy identifying possible Scotist backgrounds (Beck 2007; Burton 2012) while others, in some continuity with a line of older scholarship, have identified Thomistic lines of argumentation (Rehnman 2002; Cleveland 2013). This is a line of inquiry that needs to be extended and nuanced further, both in view of the character of ongoing scholastic conversation and debate in the early modern era that yielded what is arguably an eclectic reception among the Reformed and in view of the reception by the Reformed, around and after the time of the Synod of Dort, of recent Roman Catholic thought as is often identified as the 'second scholasticism'.

Recent scholarship has evidenced both a more nuanced understanding of early modern Aristotelianism as well as a sense of the receptions, rejections, and adaptations of the new philosophies on part of Reformed thinkers (Verbeek 1992; Van Ruler 1995; Goudriaan 2006; Bac 2010). There is more to 
be done on this topic, including further studies of Reformed-Cartesian interactions, of the impact of Gassendi's Christianized Epicureanism and the mechanical philosophies (Sytsma forthcoming), and of the implications for early modern theology of the replacement of modified Aristotelianism with other philosophical models, a process largely complete in the early eighteenth century.

Second, a specific line of research on the intersection of theological and philosophical thought concerns the rise of early modern science (Mandelbrote and Van der Meer 2008) and its impact on biblical interpretation and theological formulation. We ought to move past the point of focusing on the impact of the shift from a geocentric to a heliocentric view of the solar system and the employment of a few inconclusive prooftexts to uphold geocentrism: on this point, although the Copernican model remained a point of contention for some, many theologians adapted quite easily once improved instrumentation and Newtonian science offered a suitable explanation of the heliocentric model.

Arguably, of far greater and lasting impact was the loss of the traditional approaches to substance and causality, brought about by Cartesian and Gassendian thought, the new mechanical philosophies in general, and eventually Spinoza, Locke, and Newton (Van Ruler 1991, 1995). The effects of this alteration of thought and language on Reformed theology in the eighteenth century requires further research. Similarly, there is a need to trace out interactions between theology and science in the highly varied works on socalled 'Mosaic Philosophy' or 'Mosaic Physics' written between the late sixteenth and mid-eighteenth century (Blair 2000; Leinonen 2002; Sytsma 2015).

Another significant intersection of theology with another discipline that is bearing fruit in recent research is that between theology and law. Much twentieth-century theological scholarship attempted to sever the ties between Reformed thought and the natural law tradition despite several now classic essays indicating quite the opposite (McNeill 1946; Eusden 1960; Gibbs 1971). Recent scholarship has not only demonstrated that this minority report among the older scholarship was on the right track, it has shown the direct relationship between Reformed thought on natural law and the older natural law tradition and the importance of the Reformed contribution to natural law theory in the early modern era (Grabill 2006; Witte 2007, 2009; Burton 2014) and it has demonstrated the confessional location and theological connection of jurists in Reformed circles (Goudriaan 2011), and demonstrating common ground with Lutheran jurisprudence and significant differences with Roman Catholic (Strohm 2008). Of these studies, one also illustrates the importance of archival work to identify major unpublished materials as well as demonstrating the importance of personal connections, given the close epistolary

PERICHORESIS 14.3 (2016) 
relationship of its author, the jurist Matthew Hale, and the theologian, Richard Baxter (Hale 2015).

There has also been a reassessment of textual criticism and biblical interpretation in the early modern era (Van Rooden 1989; Austin 2007; Burnett 2012) and there have been exegetical studies that extend the reassessment of pre-critical exegesis into the seventeenth century (Lee 2009). There is a series of issues that ought to be further explored. Most directly, there is the issue of the varied nature and character of pre-critical exegesis in its own right-specifically its understanding of the literal sense of the text as illustrated in the work of exegetes, its relation to, rejection and retention of patterns of medieval exegesis, its development of text-critical approaches, and its varied forms, notably, critical annotation, theological annotation, large-scale textual and theological commentaries, homiletical commentaries, and various combinations of these genres. Beyond this there is the issue of changing patterns of biblical interpretation in relation to the philosophical and scientific developments of the era-and, further, the relation of all of these genres of interpretation and patterns of exposition to theological formulation.

Looking past the late seventeenth century, more work needs to be done on the dramatic alteration of biblical interpretation that came in the wake of Richard Simon's critical analyses of the Old and New Testaments (Champion 1999)—as well as the impact of Spinoza's and Meyer's contributions to the alteration of the understanding of Scripture (Verbeek 2000; Meijer 2005). Work has been done on the academic, critical study of the text in the eighteenth century (Legaspi 2010), but more is needed before we can have a sense of the impact of altered patterns of exegesis on theological formation-or, indeed, on the level of impact of the altered patterns and of the levels to which they were either resisted or ignored.

Finally, the question of the transition from the era of orthodoxy to the Enlightenment remains one of the topics in greatest need of investigation. The question can be addressed institutionally and as a philosophical transition (Heyd 1982; Pitassi 1992). It can also be addressed in terms of the decline of strict confessionality and the early latitudinarian theologies. These theologies tended to hold to a broadly conceived churchly orthodoxy that dispensed with disputes over predestination and advocated traditional trinitarianism while at the same time adjusting to the new philosophies and drawing positively on developments in science (Spellman 1993). Patterns of deconfessionalization and transitional or latitudinarian theology in Geneva have been analyzed (Klauber 1994; Fatio 2015), the study of the history of 'religious enlightenment' in Scotland has seen several significant developments, including an analysis of the impact of the issue of moralism on orthodoxy and Moderatism (Ahnert 2014), and the broader patterns of the 'Religious Enlighten- 
ment' throughout Europe have been surveyed (Sorkin 2009)—pointing toward a variety of religious, theological, and philosophical approaches more intellectually and regionally diverse than have been argued in recent scholarship on Spinozism (Israel 2001). The social and political contexts of deconfessionalization in varies locations require further study, including the impact of these contexts on religious practice and theological formulation.

\section{Conclusion}

In sum, the directions for research on the subject of early modern Reformed thought must begin with further effort to identify and analyze developments in theology with reference to immediate institutional philosophical, political, and socio-cultural contexts, carried on with more detailed approaches to individual thinkers and their interrelationships. Use of expanded digital resources, whether printed texts, manuscripts, or catalogues is imperative, as is archival research. There needs also to be increasing interdisciplinary dialogue given not only the importance of such fields as the histories of philosophy, science, and law to an understanding of the era, but also given the multiple competencies of the early modern writers and the breadth of interactions among the disciplines in the early modern era. And finally, there needs to be further work on the rise and decline of orthodoxy-namely on aspects of the orthodoxy that arose over the course of several generations and on the alterations that took place in the late seventeenth and eighteenth centuries to bring about not the end but the marginalization of orthodoxy.

\section{Bibliography}

Ahnert T (2014) The Moral Culture of the Scottish Enlightenment, 1690-1805. New Haven, CT: Yale University Press.

Appold KG (2004) Orthodoxie als Konsensbildung. Das theologische Disputationswesen an der Universität Wittenberg zwischen 1570 und 1710. Tübingen: Mohr Siebeck.

Atkinson N (1997) Richard Hooker and the Authority of Scripture, Tradition, and Reason: Reformed Theologian of the Church of England? Carlisle: Paternoster.

Austin K (2007) From Judaism to Calvinism. The Life and Writings of Immanuel Tremellius (c. 1510-1580). Burlington: Ashgate.

Bac JM (2010) Perfect Will Theology: Divine Agency in Reformed Scholasticism as against Suárez, Episcopius, Descartes, and Spinoza. Leiden: Brill.

Beck A (2007) Gisbertus Voetius (1589-1676). Sein Theologieverständnis und seine Gotteslehre. Göttingen: Vandenhoeck \& Ruprecht.

Blair A (2000) Mosaic Physics and the Search for a Pious Natural Philosophy in the Late Renaissance. Isis 91(1): 32-58.

Burnett AN (2006) Teaching the Reformation: Ministers and Their Message, 15291629. New York, NY: Oxford University Press. 
Burnett S (2012) Christian Hebraism in the Reformation Era (1500-1660): Authors, Books, and the Transmission of Jewish Learning. Leiden: Brill.

Burton SJG (2012) The Hallowing of Logic: The Trinitarian Method of Richard Baxter's Methodus Theologiae. Leiden: Brill.

Burton SJG (2014) Samuel Rutherford's Euthyphro Dilemma: A Reformed Perspective on the Scholastic Natural Law Tradition. In Denlinger A (ed) Reformed Orthodoxy in Scotland Edinburgh: T\&T Clark, pp. 123-139.

Champion JAI (1999) Père Richard Simon and English Biblical Criticism, 1680-1700. In Force JE et al. (eds) Everything Connects. In Conference with Richard H. Popkin: Essays in his Honor. Leiden: Brill, pp. 39-61.

Cleveland C (2013) Thomism in John Owen. Burlington: Ashgate.

Coffey J (1997) Politics, Religion, and the British Revolutions. The Mind of Samuel Rutherford. Cambridge: Cambridge University Press.

Coffey J (2006) John Goodwin and the Puritan Revolution: Religion and Intellectual Change in Seventeenth-Century England. Woodbridge: Boydell Press.

De Boer E (2012) The Genevan School of the Prophets: The Congrégations of the Company of Pastors and their Influence in 16th Century Europe. Genève: Droz.

Eusden JD (1958) Natural Law and Covenant Theology in New England, 1620-1670. Natural Law Forum 5(n.i.): 1-30.

Fatio O (1976) Méthode et théologie: Lambert Daneau et les débuts de la scolastique reformée. Genève: Droz.

Fatio O (2015) Louis Tronchin: une transition calvinienne. Paris: Garnier, 2015.

Feingold M and Navarro-Brotons V (2006) Universities and Science in the Early Modern Period. Dordrecht: Springer.

Freedman J (1994) Classifications of Philosophy, the Sciences, and the Arts in Sixteenth- and Seventeenth-Century Europe. The Modern Schoolman 72(n.i.): 37-65.

Freedman JS (2005) Disputations in Europe in the Early Modern Period. In Freedman JS (eds) Hora Est! On Dissertations. Leiden: Leiden University Library, pp. 30-50.

Gibbs LW (1971) Puritan Natural Law Theory in William Ames. Harvard Theological Review 64(1): 37-57.

Gootjes A (2014) Claude Pajon (1626-1685) and the Academy of Saumur. The First Controversy Over Grace. Leiden: Brill.

Gootjes A (forthcoming) The Theologian's Private Cabinet: The Development and Early Reception of John Cameron's Universalism. In Van der Pol F (ed) The Doctrine of Election in Reformed Perspective. Göttingen: Vandenhoeck \& Ruprecht.

Goudriaan A (2006) Reformed Orthodoxy and Philosophy, 1625-1750. Gisbertus Voetius, Petrus van Mastricht, and Anthonius Driessen. Leiden: Brill. 
Goudriaan A (2011) Ulrik Huber (1636-1694) and John Calvin. The Franeker Debate on Human Reason and the Bible (1686-1687). Church History and Religious Culture 91(1):165-178.

Grabill SJ (2006) Rediscovering the Natural Law in Reformed Theological Ethics. Grand Rapids: Eerdmans, 2006.

Gribben C (2014) The Irish Puritans. James Ussher and the Reformation of the Church. Eugene, OR: Wipf and Stock.

Gribben C (2016) John Owen and English Puritanism. Experiences of Defeat. Oxford: Oxford University Press.

Gunnoe C (2011) Thomas Erastus and the Palatinate. A Renaissance Physician in the Second Reformation. Leiden: Brill.

Hale M (2015) Of the Law of Nature [edited, with an introduction by David S. Sytsma]. Grand Rapids: CLP Academic.

Hampton S (2007) Anti-Arminians. The Anglican Reformed Tradition from Charles II to George I. Oxford: Oxford University Press.

Haykin MAG and Jones M, eds (2011) Drawn into Controversie. Reformed Theological Diversity and Debates within Seventeenth-Century British Puritanism. Göttingen: Vandenhoeck \& Ruprecht.

Heyd M (1982) Between Orthodoxy and the Enlightenment. Jean-Robert Chouet and the Introduction of Cartesian Science in the Academy of Geneva. Den Haag: Martinus Nijhoff.

Hotson H (2000) Johann Heinrich Alsted, 1588-1638. Between Renaissance, Reformation, and Universal Reform. Oxford: Clarendon Press.

Hotson H (2007) Commonplace Learning. Ramism and its German Ramifications, 1543-1630. Oxford: Oxford University Press.

Israel JI (2001) Radical Enlightenment. Philosophy and the Making of Modernity, 1650-1750. Oxford: Oxford University Press.

Kirby WJT (2000) The Theology of Richard Hooker in the Context of the Magisterial Reformation. Princeton: Princeton Theological Seminary.

Klauber MI (1994) Between Reformed Scholasticism and Pan-Protestantism. JeanAlphonse Turretin (1671-1737) and Enlightened Orthodoxy at the Academy of Geneva. Selinsgrove: Susquehanna University Press.

Lee BJ (2009) Johannes Cocceius and the Exegetical roots of Federal Theology. Reformation Developments in the Interpretation of Hebrews 7-10. Göttingen: Vandenhoeck \& Ruprecht.

Legaspi MC (2010) The Death of Scripture and the Rise of Biblical Studies. New York, NY: Oxford University Press.

Leinonen M (2002) De Physica Mosaica Comeniana. The Academic Thesis of Anders Lundbom. Acta Comeniana 15-16(39-40): 107-125.

Lim PC (2012) Mystery Unveiled. The Crisis of the Trinity in Early Modern England. New York, NY: Oxford University Press. 
Maag K (1995) Seminary or University? The Genevan Academy and Reformed Higher Education, 1560-1620. Aldershot: Scolar.

Mandelbrote S and Van der Meer J, eds (2008) Nature and Scripture in the Abrahamic Religions: 1700-Present, volumes 1-2. Leiden: Brill.

McNeill JT (1946) Natural Law in the Teaching of the Reformers. Journal of Religion 26(3): 168-182.

Meijer L (2005) Philosophy as the Interpreter of Holy Scripture (1666) [translated by Samuel Shirley, with an introduction and notes by Lee C. Rice and Francis Pastijn]. Milwaukee, WI: Marquette University Press.

Milton A (1995) Catholic and Reformed. The Roman and Protestant Churches in English Protestant Thought, 1600-1640. Cambridge: Cambridge University Press.

Moore JD (2007) English Hypothetical Universalism: John Preston and the Softening of Reformed Theology. Grand Rapids, MI: Eerdmans.

Mortimer S (2010) Reason and Religion in the English Revolution. The Challenge of Socinianism. Cambridge: Cambridge University Press.

Muller R (2012) Calvin and the Reformed Tradition. On the Work of Christ and the Order of Salvation. Grand Rapids, MI: Baker.

Pederson R (2014) Unity in Diversity. English Puritans and the Puritan Reformation, 1603-1689. Leiden: Brill.

Pitassi MC (1992) De l'Orthodoxie aux Lumières. Genève 1670-1737. Genève: Labor et Fides.

Rehnman S (2002) Divine Discourse. The Theological Methodology of John Owen. Grand Rapids, MI: Baker Book House.

Rester TM (2016) Theologia Viatorum. Institutional Continuity, Theological Pedagogy, and the Reception of a Prolegomenal Framework in Bernhardinus De Moor's 'Commentarius Perpetuus'. PhD Thesis, Calvin Theological Seminary.

Snoddy R (2014) The Soteriology of James Ussher. The Act and Object of Saving Faith. Oxford: Oxford University Press.

Sorkin David (2009) The Religious Enlightenment. Protestants, Jews, and Catholics from London to Vienna. Princeton, NJ: Princeton University Press.

Spellman WM (1993) The Latitudinarians and the Church of England, 1660-1700. Athens, GA, and London: University of Georgia Press.

Stanglin K (2010) The Missing Public Disputations of Jacobus Arminius. Introduction, Text, and Notes. Leiden: Brill.

Strohm C (2008) Calvinismus und Recht. Weltanschaulich-konfessionelle Aspekte im Werk reformierter Juristen in der Frühen Neuzeit. Tübingen: Mohr Siebeck.

Sytsma D (2015) Calvin, Daneau, and Physica Mosaica. Neglected Continuities at the Origins of an Early Modern Tradition. Church History and Religious Culture 95(4): 457-476.

Sytsma D (forthcoming) Richard Baxter and the Mechanical Philosophers. New York, NY: Oxford University Press. 
Van Asselt WJ (1996) Ultimum Tempus Nobis Imminet. Eschatologische Structuren van de Theologie van Johannes Cocceius. Nederlands Archief voor Kerkgescheidenis 76(n.i.): 189-226.

Van Asselt WJ (1997) Johannes Coccejus. Portret van een zeventiende-eeuws theoloog op oude en nieuwe wegen. Heerenveen: Groen en Zoon.

Van Asselt WJ (2000) Structural Elements in the Eschatology of Johannes Cocceius. Calvin Theological Journal 35(1): 76-104.

Van Asselt WJ (2001) The Federal Theology of Johannes Cocceius (1603-1669) [translated by Raymond A. Blacketer]. Leiden: Brill.

Van den Brink GA (2008) Herman Witsius en het antinomianisme: met tekst en vertaling van de Animadversiones Irenicae. Apeldoorn: Instituut voor Reformatieonderzoek.

Van den Brink GA (2016) Tot zonde gemaakt. De Engelse antinomiaanse controverse (1690-1700) over de toerekening van de zonden aan Christus, met bijzondere aandacht voor Herman Witsius' Animadversiones Irenicae (1696). Kampen: Summum Academic.

Van den Brink G and Höpfl HM, eds (2015) Calvinism and the Making of the European Mind. Leiden: Brill.

Van Rooden PT (1989) Theology, Biblical Scholarship, and Rabbinical Studies in the Seventeenth Century. Constantijn l'Empereur (1591-1648), Professor of Hebrew and Theology at Leiden [translated by J. C. Grayson]. Leiden: Brill.

Van Ruler JA (1991) New Philosophy to Old Standards. Voetius' Vindication of Divine Concurrence and Secondary Causality. Nederlands Archief voor Kerkgeschiedenis 71(n.i.): 58-91.

Van Ruler JA (1995) The Crisis of Causality. Voetius and Descartes on God, Nature, and Change. Leiden: Brill.

Verbeek T (1992) Descartes and the Dutch: Early Reactions to Cartesianism (16371650) [Journal of the History of Philosophy Monograph Series]. Carbondale, IL: Southern Illinois University Press, 1992.

Verbeek T (2000) L’Impossibilité de la théologie: Meyer et Spinoza. In Benitez M, McKenna A, Paganini G, and Salem J (eds) Materia actuosa: Antiquité, âge classique, Lumières. Mélanges en l'honneur d'Olivier Bloch. Paris: Champion, pp. 273-298.

Wallace DD (2011) Shapers of English Calvinism, 1660-1714. Variety, Persistence, and Transformation. New York, NY: Oxford University Press.

Witte J (2007) The Reformation of Rights. Law, Religion, and Human Rights in Early Modern Calvinism. Cambridge: Cambridge University Press.

Witte J (2009) A Demonstrative Theory of Natural Law. Johannes Althusius and the Rise of Calvinist Jurisprudence. Ecclesiastical Law Journal 11(3): 248-265.

PERICHORESIS 14.3 (2016) 